\title{
The fertilizing capacity of epididymal spermatozoa in the pig
}

\author{
W. Holtz and D. Smidt \\ Institut für Tierzucht und Haustiergenetik der Universität Göttingen, \\ 34 Göttingen, Albrecht-Thaer-Weg 1, West-Germany
}

In all mammals studied so far, with the possible exception of man, it has been shown that sperm cells emerging from the testis have to pass through at least part of the epididymis before they acquire the ability to fertilize (Bedford, Calvin \& Cooper, 1973; Bedford, 1974).

The literature regarding the fertilizing capacity of spermatozoa collected from different segments of the epididymis in laboratory animals has been summarized by Paufler \& Foote (1968) and OrgebinCrist (1969). Little information is available for the large domestic species although bulls have been successfully inseminated with spermatozoa from the cauda epididymidis (Lardy \& Ghosh, 1952; Barker, 1954; Igboeli \& Foote, 1968).

The present experiments were therefore conducted to examine the fertilizing capacity of spermatozoa from different regions of the epididymis in the domestic pig.

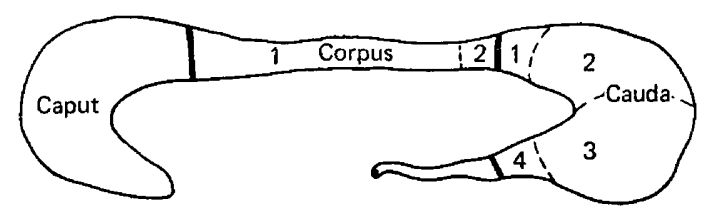

Text-fig. 1. Diagram showing the segments into which the boar epididymis was divided.

Epididymides were obtained by castrating sexually rested 7-24-month-old German Landrace boars under sodium pentobarbital anaesthesia. Each epididymis was divided into segments (Textfig. 1). Initially, the segments were the caput, corpus, proximal and distal cauda epididymidis. In subsequent experiments the distal $1 \mathrm{~cm}$ of the corpus (Corpus 2), the most proximal (Cauda 1), and the terminal (Cauda 4) portion of the cauda were studied. Each segment was placed in a fine-meshed plastic sieve, submerged in physiological saline at room temperature, and minced gently but thoroughly with fine scissors to provide a suspension of largely intact spermatozoa almost free of contamination with blood or other tissue. Suspensions from similar epididymal segments of several boars were pooled to eliminate individual boar effects.

Sperm density was determined by counting two representative samples taken from each suspension. After diluting the samples 5-10 times depending on sperm density, haemocytometers were filled and placed in a moist atmosphere for $5 \mathrm{~min}$ before counting commenced. Insemination doses of $120 \mathrm{ml}$, each containing a minimum of $5 \times 10^{9}$ spermatozoa, were prepared by adding saline. Processing time in the laboratory was about $2 \mathrm{hr}$ and the time between castration and insemination was 4-6 hr.

For the inseminations, prepubertal Landrace gilts weighing about $75-85 \mathrm{~kg}$ were given a single i.m. injection of a combination of 400 i.u. PMSG and 200 i.u. HCG (PG 600: Intervet International), and inseminated without regard to oestrous symptoms on Days 4 and 5 after the injection. The animals were killed 3-4 weeks after insemination and the ovaries and uterine contents inspected.

Of the 141 gilts treated, $119(84 \%)$ responded to the gonadotrophin treatment with 5 or more ovulations, as judged by counts of $\mathrm{CL}$, and were included in the experiment. Table 1 summarizes the results obtained in 11 trials. The fertilization rate was very poor when caput spermatozoa were used, improved with spermatozoa from the corpus, and good with those from the proximal and distal cauda epididymidis. The results with spermatozoa from more specific areas of the epididymis indicate that the changes spermatozoa undergo while passing through the epididymis have not been completed by the time they enter the cauda. There could be a lack of uniformity in the stage of 
maturity reached by the sperm cells in any one segment because of mixing within the epididymis. The good fertility observed when inseminating gilts with spermatozoa from the terminal portion of the epididymis (Cauda 4) suggests that, even in sexually rested boars, these spermatozoa are not necessarily aged.

Table 1. The results of insemination of gilts with spermatozoa from different segments of the epididymis (see Text-fig. 1)

\begin{tabular}{|c|c|c|c|c|c|}
\hline \multirow[b]{2}{*}{ Epididymal segment } & \multirow{2}{*}{$\begin{array}{l}\text { No. of gilts } \\
\text { inseminated }\end{array}$} & \multicolumn{2}{|c|}{ Gilts pregnant } & \multirow{2}{*}{$\begin{array}{c}\text { No. of live } \\
\text { fetuses/gilt } \\
\text { (mean } \pm \text { S.D.) }\end{array}$} & \multirow{2}{*}{$\begin{array}{l}\% \text { Embryo loss* } \\
\text { (mean } \pm \text { S.D.) }\end{array}$} \\
\hline & & No. & $\%$ & & \\
\hline Caput & 25 & 2 & 8 & $8.0 \pm 0.0$ & $35 \cdot 5 \pm 19 \cdot 0$ \\
\hline Corpus $(1+2)$ & 19 & 5 & 26 & $7 \cdot 2 \pm 5 \cdot 2$ & $57.6 \pm 45.9$ \\
\hline Corpus (2) & 12 & 3 & 25 & $4 \cdot 8 \pm 5 \cdot 3$ & $52 \cdot 3 \pm 43 \cdot 6$ \\
\hline Cauda (1) & 18 & 9 & 50 & $10 \cdot 9 \pm 6.1$ & $40 \cdot 2 \pm 11 \cdot 9$ \\
\hline Cauda $(1+2)$ & 12 & 10 & 83 & $8 \cdot 6 \pm 2 \cdot 4$ & $30 \cdot 0 \pm 11 \cdot 3$ \\
\hline Cauda $(3+4)$ & 19 & 15 & 79 & $9.3 \pm 2.8$ & $27 \cdot 9 \pm 7 \cdot 2$ \\
\hline Cauda (4) & 14 & 11 & 79 & $8 \cdot 2 \pm 4 \cdot 2$ & $33 \cdot 3 \pm 11 \cdot 7$ \\
\hline
\end{tabular}

* Discrepancy between the no. of $\mathrm{CL}$ and the no. of embryos.

The average litter size of 8.7 live fetuses was reasonable, considering the age of the gilts, although individual variation was high. The overall frequency of non-viable or degenerating embryos $(5.6 \%)$ was within normal limits, and only one deformed fetus (cyclops) was found.

No pronounced relationship between the epididymal segment and litter size could be detected The decrease in embryonic mortality mentioned by Orgebin-Crist (1969) when inseminating rabbits with spermatozoa from the more distal segments of the epididymis could not be confirmed for the pig, although the number of gilts conceiving after insemination with caput and corpus spermatozoa was small. Since no examinations were conducted earlier in pregnancy the embryonic loss may have been even higher because total litter loss could not be determined (see Perry \& Rowlands, 1962).

In additional experiments, gilts were inseminated with spermatozoa from the caput, corpus or cauda epididymidis ( 5 gilts in each group) on Days 3 and 4 after gonadotrophin treatment. Ovulation occurred in all gilts but none became pregnant. When spermatozoa from the caput and corpus epididymidis were incubated for $4 \mathrm{hr}$ at $36^{\circ} \mathrm{C}$ in a saline solution containing a high proportion of plasma from the cauda epididymidis, $0 / 5$ gilts inseminated with caput spermatozoa became pregnant and the 2 pregnant gilts of the 5 inseminated with corpus spermatozoa had only 3 and 2 live fetuses, respectively. Insemination of 5 gilts with caput spermatozoa that had been incubated in boar seminal plasma for $4 \mathrm{hr}$ at $36^{\circ} \mathrm{C}$ did not result in any pregnancies.

The physiological maturation of boar spermatozoa is not therefore an abrupt event but rather a gradual process whereby increasing numbers of spermatozoa achieve the capacity to fertilize as they move down the epididymal duct. An in-vitro period of contact with secretions from the cauda epididymidis or the accessory glands does not appear to be sufficient to bring about the maturation changes leading to the ability to fertilize in spermatozoa originating from the proximal segments of the epididymis.

We thank particularly Mrs J. Ebeling, Miss I. Labs and Mr H. Wendhausen for their assistance and Vemie GmbH (Intervet International) for donating the PG 600.

\section{References}

BARKER, C.A.V. (1954) Low temperature preservation of bovine epididymal spermatozoa. Can. J. comp. Med. 18, 390.
BEDFORD, J.M. (1974) Maturation of the fertilizing ability of mammalian spermatozoa in the male and female reproductive tract. Biol. Reprod. 11, 346-362. 
Bedford, J.M., Calvin, H. \& CoOper, G.W. (1973) The maturation of spermatozoa in the human epididymis. J. Reprod. Fert., Suppl. 18, 199-213.

IgBoel, G. \& Foote, R.H. (1968) Maturation changes in bull epididymal spermatozoa. J. Dairy Sci. 51, 1703-1705.

LARDY, H.A. \& GHosh, D. (1952) Comparative metabolic behavior of epididymal and ejaculated mammalian spermatozoa. Ann. N.Y. Acad. Sci. 55, $594-596$.
Orgebin-Crist, M.C. (1969) Studies on the function of the epididymis. Biol. Reprod., Suppl. 1, 155-175.

Paufler, S.K. \& Foote, R.H. (1968) Morphology, motility and fertility of spermatozoa recovered from different areas of ligated rabbit epididymides. J. Reprod. Fert. 17, 125-137.

Perry, J.S. \& Rowlands, I.W. (1962) Early pregnancy in the pig. J. Reprod. Fert. 4, 175-188.

Received 28 April 1975 